Rowan University

Rowan Digital Works

$1-12-2013$

\title{
An Investigation of Interactions Between Hypocretin/Orexin Signaling and Glutamate Receptor Surface Expression in the Rat Nucleus Accumbens Under Basal Conditions and After Cocaine Exposure
}

\author{
Ainhoa Plaza-Zabala \\ Pompeu Fabra University \\ Xuan Li \\ Rosalind Franklin University of Medicine and Science \\ Mike Milovanovic \\ Rosalind Franklin University of Medicine and Science \\ Jessica Loweth \\ Rowan University School of Osteopathic Medicine \\ Ralfar| tMaldectional works at: https://rdw.rowan.edu/som_facpub \\ J mpeu Fabra University \\ Part of the Amino Acids, Peptides, and Proteins Commons, Biochemistry Commons, Biology \\ Commons, Endocrinology Commons, Molecular and Cellular Neuroscience Commons, and the Substance \\ Sibemexthplagedfieriadditional authors
}

\section{Recommended Citation}

Plaza-Zabala A, Li X, Milovanovic M, Loweth JA, Maldonado R, Berrendero F, Wolf ME. An investigation of interactions between hypocretin/orexin signaling and glutamate receptor surface expression in the rat nucleus accumbens under basal conditions and after cocaine exposure. Neuroscience Letters. 2013 Dec 17;557 Pt B:101-6. Epub 2013 Oct 26. doi: 10.1016/j.neulet.2013.10.038. PMID: 24262606. PMCID: PMC3869201.

This Article is brought to you for free and open access by the School of Osteopathic Medicine at Rowan Digital Works. It has been accepted for inclusion in School of Osteopathic Medicine Faculty Scholarship by an authorized administrator of Rowan Digital Works. 


\section{Authors}

Ainhoa Plaza-Zabala, Xuan Li, Mike Milovanovic, Jessica Loweth, Rafael Maldonado, Fernando Berrendero, and Marina Wolf 


\title{
An investigation of interactions between hypocretin/orexin signaling and glutamate receptor surface expression in the rat nucleus accumbens under basal conditions and after cocaine exposure
}

\author{
Ainhoa Plaza-Zabala ${ }^{2}$, Xuan Li $^{1}$, Mike Milovanovic ${ }^{1}$, Jessica A. Loweth ${ }^{1}$, Rafael \\ Maldonado $^{2}$, Fernando Berrendero ${ }^{2}$, and Marina E. Wolf ${ }^{1, \#}$ \\ ${ }^{1}$ Department of Neuroscience, Rosalind Franklin University of Medicine and Science, 3333 Green \\ Bay Road, North Chicago, IL 60064, USA \\ ${ }^{2}$ Laboratory of Neuropharmacology, Department of Experimental and Health Sciences, \\ Universitat Pompeu Fabra, PRBB, C/Doctor Aiguader 88, 08003 Barcelona, Spain
}

\begin{abstract}
Hypocretin peptides are critical for the effects of cocaine on excitatory synaptic strength in the ventral tegmental area (VTA). However, little is known about their role in cocaine-induced synaptic plasticity in the nucleus accumbens (NAc). First, we tested whether hypocretin-1 by itself could acutely modulate glutamate receptor surface expression in the NAc, given that hypocretin-1 in the VTA reproduces cocaine's effects on glutamate transmission. We found no effect of hypocretin-1 infusion on AMPA or NMDA receptor surface expression in the NAc, measured by biotinylation, either $30 \mathrm{~min}$ or $3 \mathrm{~h}$ after the infusion. Second, we were interested in whether changes in hypocretin receptor-2 (Hcrtr-2) expression contribute to cocaine-induced plasticity in the NAc. As a first step towards addressing this question, Hcrtr-2 surface expression was compared in the NAc after withdrawal from extended-access self-administration of saline (control) versus cocaine. We found that surface Hcrtr-2 levels remain unchanged following 14, 25 or 48 days of withdrawal from cocaine, a time period in which high conductance GluA2-lacking AMPA receptors progressively emerge in the NAc. Overall, our results fail to support a role for hypocretins in acute modulation of glutamate receptor levels in the NAc or a role for altered Hcrtr-2 expression in withdrawal-dependent synaptic adaptations in the NAc following cocaine self-administration.
\end{abstract}

\section{Keywords}

hypocretin; orexin; cocaine; glutamate receptor; synaptic plasticity; nucleus accumbens

\section{Introduction}

The hypocretin/orexin system was co-discovered by 2 independent groups during the late 1990s (1,2). It is composed of 2 neuropeptides, hypocretin-1/orexin-A and hypocretin-2/

\footnotetext{
(C) 2013 Elsevier Ireland Ltd. All rights reserved.

\#Correspondence: Marina E. Wolf, Tel: 847-578-8659; Fax: 847-578-8515; marina.wolf@ rosalindfranklin.edu.
}

Publisher's Disclaimer: This is a PDF file of an unedited manuscript that has been accepted for publication. As a service to our customers we are providing this early version of the manuscript. The manuscript will undergo copyediting, typesetting, and review of the resulting proof before it is published in its final citable form. Please note that during the production process errors may be discovered which could affect the content, and all legal disclaimers that apply to the journal pertain. 
orexin-B $(1,2)$, which bind to 2 G-protein-coupled receptors, hypocretin/orexin receptor-1 and hypocretin/orexin receptor-2 (2). Hypocretin receptor-2 (Hcrtr-2) binds with equal affinity to both peptides, whereas hypocretin receptor-1 (Hcrtr-1) binds with 100-1000 fold higher affinity to hypocretin-1 (2). In the CNS, hypocretin peptides are exclusively localized in a subregion of the hypothalamus, including the lateral, perifornical and dorsomedial hypothalamus $(1,2)$. Nevertheless, they project widely throughout the brain (3), including brain areas associated with drug reward and addiction, such as the ventral tegmental area (VTA) and the nucleus accumbens (NAc) (3-5). Indeed, although initially hypocretins were described as regulators of food intake and sleep homeostasis $(2,6)$, evidence has accumulated over the last decade to support an important role in drug addiction $(7,8)$.

The modulation of cocaine-induced synaptic plasticity is one mechanism by which hypocretins might influence cocaine addiction (9). Indeed, bath application of hypocretin-1 to VTA-containing slices mimicked cocaine's effects on synaptic plasticity (10). Thus, similar to cocaine (11), hypocretin-1 increased the AMPA/NMDA ratio in VTA dopamine (DA) neurons (10). Moreover, the Hcrtr-1 antagonist SB334867 blocked the enhancement of the AMPA/NMDA ratio in rats receiving a sensitizing regimen of cocaine (10).

Interestingly, the same antagonist administered systemically or into the VTA also prevented the acquisition of cocaine-elicited locomotor sensitization (10), which indicates that Hcrtr-1 activation in VTA DA neurons is necessary for the development of behavioral sensitization to cocaine, possibly through the facilitation of synaptic plasticity mechanisms.

Hcrtr-1 signaling has also been implicated in the reinstatement of previously extinguished cocaine-seeking. Thus, intracerebral (12) or intra-VTA (13) infusion of hypocretin-1 elicited reinstatement of previously extinguished cocaine-seeking in rats. Conversely, Hcrtr-1 antagonists reduced stress- $(12,14)$, cue- $(15,16)$, and context- $(17)$, but not cocaine-primed $(14,16,18,19)$, reinstatement of extinguished cocaine-seeking. In the case of cue-induced reinstatement $(19,20)$, but not stress- (13) or cocaine-primed (19) reinstatement, Hcrtr-1 antagonists were effective when infused directly into the VTA.

Although hypocretin-glutamate receptor interactions occur in the dorsal striatum of young animals (21) (see Discussion), it is unknown whether hypocretins acutely regulate glutamate receptor surface expression in the NAc or whether cocaine self-administration alters hypocretin receptor expression in the NAc. To address these distinct questions, we performed 2 studies. First, given that hypocretin-1 signaling is sufficient to increase AMPA/ NMDA ratios in the VTA (10) and striatum (21), we determined if hypocretin-1 infusion into the NAc of drug-naïve rats altered AMPAR or NMDA receptor (NMDAR) surface expression. Second, we analyzed surface expression of Hcrtr-2, the main hypocretin receptor subtype in the NAc (22-25), in the 'incubation of cocaine craving' model. Incubation refers to the progressive enhancement of cue-induced cocaine-seeking that occurs during withdrawal from extended-access cocaine self-administration in rodents (26). It relies on glutamate plasticity in the NAc, namely a delayed but persistent increase in high conductance GluA2-lacking, $\mathrm{Ca}^{2+}$-permeable AMPARs (CP-AMPARs) that strengthens baseline excitatory synaptic transmission onto NAc medium spiny neurons (27-29). Once CP-AMPARs have accumulated in the NAc, their activation is required for expression of incubation (27). To determine if Hcrtr-2 function is altered in conjunction with this plasticity, we measured Hcrtr-2 surface expression at withdrawal times bracketing the emergence of CP-AMPARs (29). Cue-induced cocaine seeking also increases over this time period (26). 


\section{Materials and methods}

\section{Animals}

Male Sprague-Dawley rats (270-320g) were housed (3/cage) on a $12 \mathrm{~h} / 12 \mathrm{~h}$ light/dark cycle (lights on at 7AM) with food and water available ad libitum. Rats acclimated for 7 days prior to use. All procedures were approved by the Institutional Animal Care and Use Committee of Rosalind Franklin University of Medicine and Science.

\section{Intra-accumbens injections of hypocretin-1}

Rats were anesthetized with ketamine-xylazine ( 80 and $10 \mathrm{mg} / \mathrm{kg}$, respectively, i.p.) and mounted onto a stereotaxic frame. A Hamilton microsyringe was slowly lowered, and hypocretin-1 [Sigma-Aldrich, St. Louis, MO; $3 \mu \mathrm{g} / 0.5 \mu 1$, dissolved in artificial cerebrospinal fluid solution $(\mathrm{aCSF})]$ was unilaterally injected into the $\mathrm{NAc}(0.1 \mu \mathrm{l} / \mathrm{min})$. The other hemisphere served as a non-injected control. Injectors were left in place for $2 \mathrm{~min}$ after the injection. The dose of hypocretin-1 selected for our study has been previously shown to produce addiction-like effects $(12,30,31)$ without the appearance of side effects related to other functions of the hypocretin system, such as regulation of arousal. Coordinates were: anteroposterior $+1.2 \mathrm{~mm}$; mediolateral $\pm 2.6 \mathrm{~mm}\left(6^{\circ}\right.$ angle); dorsoventral $-7.0 \mathrm{~mm}$ (32). Rats were decapitated $30 \mathrm{~min}$ or $3 \mathrm{~h}$ post-injection. Hypocretin-1 was selected because it enhances post-synaptic glutamatergic transmission in VTA (10) and striatum (21) whereas hypocretin-2's role in synaptic plasticity is less clear (33).

\section{Cocaine self-administration}

As previously described (27), rats self-administered cocaine under a fixed-ratio 1 schedule in daily $6 \mathrm{~h}$ sessions on 10 consecutive days. Nose-poking in the active hole delivered an intravenous infusion of saline or cocaine $(0.5 \mathrm{mg} / \mathrm{kg} / 100 \mu \mathrm{l}$ over $3 \mathrm{~s})$, paired with a $30 \mathrm{~s}$ light cue inside the hole. Nose-poking in the inactive hole had no consequences. After the last session, rats were returned to home cages for withdrawal.

\section{Biotinylation and immunoblotting}

Rats were decapitated $30 \mathrm{~min}$ or $3 \mathrm{~h}$ after intra-accumbens injection of hypocretin- 1 or withdrawal day 14, 25 or 48 following cocaine self-administration. The NAc (core plus lateral shell) was dissected from a $2 \mathrm{~mm}$ coronal section obtained using a brain matrix. During the dissection, hypocretin-1 injection sites were verified to be located within the NAc. NAc tissue was minced and biotinylated as described previously (34). To recover biotinylated proteins, an aliquot of each NAc sample $(100 \mu \mathrm{g})$ was added to $37.5 \mu \mathrm{l}$ of NeutrAvidin Agarose beads (Thermo Scientific) and incubated overnight at $4^{\circ} \mathrm{C}$ on an endover-end rotator. Bound proteins were isolated from the non-biotinylated (unbound) fraction by centrifugation (3000 RPM, $1 \mathrm{~min}$ ) and washed several times in ice-cold lysis buffer (34). The biotinylated fraction was then dissolved in 2X Laemmli sample buffer with DTT $(100 \mathrm{mM})$ and the process was repeated to ensure complete separation of bound/unbound fractions. Bound fractions were pooled and heated at $97^{\circ} \mathrm{C}$ for $3 \mathrm{~min}$ to release the biotinylated proteins from the beads. Samples were spun (10000 RPM, 5 min) on a centrifugal filter unit $(0.45 \mathrm{~mm}$, \#UFC30HV00, Millipore, Billerica, MA) to remove the beads and stored at $-20^{\circ} \mathrm{C}$. After SDS-PAGE and transfer to membranes (34), blots were incubated with the following primary antibodies overnight at $4{ }^{\circ} \mathrm{C}$ : GluA1 (1308-1, 1:1000; Epitomics, Inc, CA, USA), GluA2 (75-002, 1:200; UC Davis/NINDS/NIMH NeuroMab Facility, CA, USA), GluA3 (3437, 1:1000; Cell Signaling Technology, Inc, Danvers, MA), GluN1 (NB300-118, 1:1000; Novus Biologicals), GluN2A (sc-1468, 1:2000; Santa Cruz Biotechnology, Inc), GluN2B (454582, 1:2000; Calbiochem), and Hcrtr-2 (OX2R21-A, 1:500, Alpha Diagnostic, San Antonio, TX). Immunoblots were processed using 
chemiluminiscence (ECL) detecting substrate (GE Healthcare, Piscataway, NJ) and analyzed with Total Lab software (Life Sciences Analysis Essentials) (34).

\section{Statistical analysis}

Paired Student's $t$ tests were used to compare surface AMPAR and NMDAR subunit levels between hypocretin-injected and non-injected hemispheres. Surface Hcrtr-2 levels were compared between saline and cocaine groups using unpaired Student's $t$ tests. Significance was set at $p<0.05$.

\section{Results \\ Hypocretin-1 infusion into the NAc does not influence AMPAR or NMDAR surface expression}

To evaluate possible effects of hypocretin-1 on glutamate receptor surface expression, unilateral injections of hypocretin- 1 were made directly into the NAc $(3 \mu \mathrm{g} / 0.5 \mu \mathrm{l})$. The contralateral hemisphere was used as a non-injected control. We did not use vehicle controls because we showed previously that vehicle injection does not alter glutamate receptor surface expression in the NAc (35). Based on the time course of hypocretin-1's effects in VTA (10), rats were killed either $30 \mathrm{~min}$ or $3 \mathrm{~h}$ after the infusion. NAc tissue (core plus shell) was dissected to measure glutamate receptor surface expression using biotinylation. No changes in NMDAR (GluN1, GluN2A, GluN2B) or AMPAR (GluA1-3) surface expression were observed at early (30 min; Fig. 1) or late (3 h; Fig. 2) time-points, suggesting that hypocretin-1 does not acutely regulate glutamate receptor surface expression in the NAc.

\section{Hypocretin receptor-2 surface expression levels are not modified in the NAc during the incubation of cocaine craving}

The incubation of cocaine-craving is associated with a delayed but persistent increase in CPAMPAR levels in the NAc $(27-29,34)$. To investigate the potential role of hypocretin transmission in this cocaine-induced plasticity, we compared surface expression of Hcrtr-2, the main receptor subtype in the NAc (22-25), at 3 time-points after discontinuing saline or cocaine self-administration: withdrawal day 14, when CP-AMPAR levels have not yet increased above the low levels present in drug-naïve rats or saline controls; withdrawal day 25, when CP-AMPARs are emerging; and withdrawal day 48, when CP-AMPARs are maximally expressed and mediate the expression of 'incubated' cue-induced cocaineseeking $(27,29)$. We failed to observe any significant difference in Hcrtr-2 surface expression between cocaine and saline groups at any time-point (Fig. 3). The antibody detected a band of $52 \mathrm{KDa}$, in agreement with the molecular weight predicted in the Uniprot database (http://www.uniprot.org/uniprot/P56719). These results indicate that Hcrtr-2 surface expression levels are not modified during the emergence of changes in excitatory synaptic transmission in the NAc during incubation of cocaine craving.

\section{Discussion}

Amassing evidence indicates that the compulsive nature of cocaine addiction together with the enduring vulnerability to relapse arises from long-term synaptic adaptations in the mesolimbic reward system, including the VTA and the NAc (36,37). In the VTA, this plasticity is modulated by hypocretin transmission (9), motivating us to perform two distinct experiments to examine interactions between hypocretin and glutamate systems in the NAc. First, we found that intra-accumbal infusion of hypocretin-1 (which activates both hypocretin-1 and hypocretin-2 receptors) did not alter NMDAR or AMPAR surface expression in the NAc. Second, we found that surface expression of Hcrtr-2, the main 
hypocretin receptor subtype in the NAc, was not altered during a period of withdrawal from extended-access cocaine self-administration that is associated with marked plasticity of excitatory synaptic transmission. While our results do not rule out functional interactions between cocaine, glutamate transmission, and hypocretin transmission in the NAc, they point to marked differences from interactions described previously in the VTA (see below).

It is well established that a single systemic injection of cocaine produces potentiation of excitatory synapses onto VTA DA neurons (indicated by an increased AMPA/NMDA ratio) that is detected as early as $3 \mathrm{~h}$ after injection $(11,38)$. This effect is thought to be achieved through a rapid enhancement of NMDAR transmission (minutes) that enables the subsequent potentiation of AMPAR transmission at $3 \mathrm{~h}$ (38). This cocaine-induced synaptic potentiation in the VTA is blocked by an Hcrtr-1 antagonist, while bath application of hypocretin-1 onto VTA-containing slices from drug-naïve rats mimics the effects of cocaine (rapid enhancement of NMDAR transmission and a later increase in the AMPA/NMDA ratio) (10). The latter result demonstrates that activation of Hcrtr-1 transmission is sufficient to elicit plasticity in the VTA of drug-naïve rats. In contrast with these findings, we found that infusion of hypocretin-1 into the NAc of drug-naïve rats does not modify surface expression of NMDAR and AMPAR subunits over the same time-frame studied in the VTA (30 min or $3 \mathrm{~h}$ ). Possible explanations for different outcomes in NAc versus VTA are described at the end of the Discussion. It should be noted that brief hypocretin exposure increased AMPAR surface expression in cultures of embryonic dorsal striatal neurons and produced a delayed increase in the AMPA/NMDA ratio in dorsal striatal neurons in slices from juvenile rats (21). The difference between these results and ours could reflect agerelated differences in plasticity mechanisms and/or differences between dorsal striatum and NAc.

Although the role of hypocretin signaling in mediating effects of cocaine and other reinforcers has been studied extensively in recent years $(8,9,39)$, only one prior study has examined whether cocaine exposure alters hypocretin receptor expression (40). This study measured Hcrtr-1 and Hcrtr-2 expression in homogenates from several brain regions after withdrawal from a repeated cocaine regimen that led to behavioral sensitization $(20 \mathrm{mg} / \mathrm{kg}$, i.p., for 5 days). In dorsal striatum, hippocampus and VTA, no changes in Hcrtr-2 levels were observed (40). In the NAc, however, Hcrtr-2 levels were increased after 1, 14, 28 or 60 days of withdrawal, whereas levels of Hcrtr-1 (as well as hypocretin-1 and -2) were unchanged (40). These results demonstrate that non-contingent cocaine increases Hcrtr-2 expression in the NAc. However, non-contingent and contingent cocaine administration can produce different neuroadaptations throughout the reward system (41) and specifically in the NAc $(34,42)$. Therefore, we extended prior results $(40)$ by examining Hcrtr-2 surface expression in the NAc after extended-access cocaine self-administration $(6 \mathrm{~h} /$ day $\times 10$ days $)$. We selected an extended-access regimen because withdrawal from such regimens leads to robust behavioral plasticity (incubation of cue-induced cocaine craving; 26) and robust synaptic plasticity in the NAc (CP-AMPAR accumulation; 27-29,34). More generally, extended-access regimens produce behavioral changes that model the compulsive drugseeking and -taking characteristic of addiction $(43,44)$. However, we failed to observe any change in Hcrtr-2 surface expression in the NAc after cocaine self-administration despite the fact that we examined 3 withdrawal days (14, 25 and 48) that encompass the time-course of CP-AMPAR plasticity during incubation.

In summary, our first study found that hypocretin infusion does not acutely alter NMDAR or AMPAR surface expression in the NAc, while our study of cocaine withdrawal indicates that a robust regimen of cocaine exposure that is associated with marked synaptic plasticity fails to alter Hcrtr-2 surface expression. Why does the role of hypocretin appear to differ so markedly between the VTA and NAc? Notably, the NAc receives far less hypocretin 
projections than the VTA. Hence, scarce to moderate hypocretin-containing fibers have been identified in the NAc $(3,4)$, and these remain restricted to its caudal and medial portions (4). On the other hand, the VTA receives moderate to strong inputs from hypocretin neurons (35), consistent with amassing behavioral and biochemical evidence identifying the VTA as a brain area subjected to hypocretin control in drug addictive processes $(8,39)$. Additionally, and contrasting with the NAc, both hypocretin receptor subtypes (Hcrtr-1 and Hcrtr-2) have been identified within the VTA, whereas the NAc contains mainly Hcrtr-2 (22-25).

Hypocretin receptors might exhibit functional dichotomy, with Hcrtr-1 having a more prominent role in reward processing and Hcrtr-2 being more connected to maintenance of arousal $(39,45)$. In line with this idea, Hcrtr-1 modulates cocaine-induced plasticity in VTA DA neurons (10), while the role of Hcrtr-2 in VTA synaptic plasticity seems to be more complex and is not completely understood (33). Similarly, a synergistic interaction between Hcrtr-1 and AMPARs in the VTA plays a key role in cue-induced reinstatement of cocaineseeking (19), consistent with evidence that cue-induced reinstatement is dependent on Hcrtr-1, but not Hcrtr-2, signaling (15). Taken together, these studies suggest that different roles of hypocretin signaling in the NAc and VTA may not be surprising.

\section{Acknowledgments}

These studies were supported by DA009621, DA0015835, DA029099 (M.E.W.) and Spanish Instituto de Salud Carlos III grants, \#PI10/00316 and \#RD06/001/001 (RTA-RETICS) (F.B.). A.P.-Z. received a fellowship for short research stays abroad under the Formación de Profesorado Universitario (FPU) program from the Spanish Ministry of Education (2011).

\section{References}

1. de Lecea L, Kilduff TS, Peyron C, Gao X, Foye PE, Danielson PE, Fukuhara C, Battenberg EL, Gautvik VT, Bartlett FS 2nd, Frankel WN, van den Pol AN, Bloom FE, Gautvik KM, Sutcliffe JG. The hypocretins: hypothalamus-specific peptides with neuroexcitatory activity. Proc Natl Acad Sci USA. 1998; 95:322-327. [PubMed: 9419374]

2. Sakurai T, Amemiya A, Ishii M, Matsuzaki I, Chemelli RM, Tanaka H, Williams SC, Richardson JA, Kozlowski GP, Wilson S, Arch JR, Buckingham RE, Haynes AC, Carr SA, Annan RS, McNulty DE, Liu WS, Terrett JA, Elshourbagy NA, Bergsma DJ, Yanagisawa M. Orexins and orexin receptors: a family of hypothalamic neuropeptides and $\mathrm{G}$ protein-coupled receptors that regulate feeding behavior. Cell. 1998; 92:573-585. [PubMed: 9491897]

3. Peyron C, Tighe DK, van den Pol AN, de Lecea L, Heller HC, Sutcliffe JG, Kilduff TS. Neurons containing hypocretin (orexin) project to multiple neuronal systems. J Neurosci. 1998; 18:999610015. [PubMed: 9822755]

4. Baldo BA, Daniel RA, Berridge CW, Kelley AE. Overlapping distributions of orexin/hypocretinand dopamine-beta-hydroxylase immunoreactive fibers in rat brain regions mediating arousal, motivation, and stress. J Comp Neurol. 2003; 464:220-237. [PubMed: 12898614]

5. Richardson KA, Aston-Jones G. Lateral hypothalamic orexin/hypocretin neurons that project to ventral tegmental area are differentially activated with morphine preference. J Neurosci. 2012; 32:3809-3817. [PubMed: 22423101]

6. Sutcliffe JG, de Lecea L. The hypocretins: excitatory neuromodulatory peptides for multiple homeostatic systems, including sleep and feeding. J Neurosci Res. 2000; 62:161-168. [PubMed: 11020209]

7. Aston-Jones G, Smith RJ, Moorman DE, Richardson KA. Role of lateral hypothalamic orexin neurons in reward processing and addiction. Neuropharmacology. 2009; 56(Suppl 1):112-121. [PubMed: 18655797]

8. Plaza-Zabala A, Maldonado R, Berrendero F. The hypocretin/orexin system: implications for drug reward and relapse. Mol Neurobiol. 2012; 45:424-439. [PubMed: 22430644]

9. Bonci A, Borgland S. Role of orexin/hypocretin and CRF in the formation of drug-dependent synaptic plasticity in the mesolimbic system. Neuropharmacology. 2009; 56(Suppl 1):107-111. [PubMed: 18694770] 
10. Borgland SL, Taha SA, Sarti F, Fields HL, Bonci A. Orexin A in the VTA is critical for the induction of synaptic plasticity and behavioral sensitization to cocaine. Neuron. 2006; 49:589-601. [PubMed: 16476667]

11. Ungless MA, Whistler JL, Malenka RC, Bonci A. Single cocaine exposure in vivo induces longterm potentiation in dopamine neurons. Nature. 2001; 411:583-587. [PubMed: 11385572]

12. Boutrel B, Kenny PJ, Specio SE, Martin-Fardon R, Markou A, Koob GF, de Lecea L. Role for hypocretin in mediating stress-induced reinstatement of cocaine-seeking behavior. Proc Natl Acad Sci USA. 2005; 102:19168-19173. [PubMed: 16357203]

13. Wang B, You ZB, Wise RA. Reinstatement of cocaine seeking by hypocretin (orexin) in the ventral tegmental area: independence from the local corticotropin-releasing factor network. Biol Psychiatry. 2009; 65:857-862. [PubMed: 19251246]

14. Zhou L, Ghee SM, Chan C, Lin L, Cameron MD, Kenny PJ, See RE. Orexin-1 receptor mediation of cocaine seeking in male and female rats. J Pharmacol Exp Ther. 2012; 340:801-809. [PubMed: 22186370]

15. Smith RJ, See RE, Aston-Jones G. Orexin/hypocretin signaling at the orexin 1 receptor regulates cue-elicited cocaine-seeking. Eur J Neurosci. 2009; 30:493-503. [PubMed: 19656173]

16. Zhou L, Smith RJ, Do PH, Aston-Jones G, See RE. Repeated orexin 1 receptor antagonism effects on cocaine seeking in rats. Neuropharmacology. 2012; 63:1201-1207. [PubMed: 22971541]

17. Smith RJ, Tahsili-Fahadan P, Aston-Jones G. Orexin/hypocretin is necessary for context-driven cocaine-seeking. Neuropharmacology. 2010; 58:179-184. [PubMed: 19591850]

18. Aston-Jones G, Smith RJ, Sartor GC, Moorman DE, Massi L, Tahsili-Fahadan P, Richardson KA. Lateral hypothalamic orexin/hypocretin neurons: A role in reward-seeking and addiction. Brain Res. 2010; 1314:74-90. [PubMed: 19815001]

19. Mahler SV, Smith RJ, Aston-Jones G. Interactions between VTA orexin and glutamate in cueinduced reinstatement of cocaine seeking in rats. Psychopharmacology (Berl). 201210.1007/ s00213-012-2681-5

20. James MH, Charnley JL, Levi EM, Jones E, Yeoh JW, Smith DW, Dayas CV. Orexin-1 receptor signalling within the ventral tegmental area, but not the paraventricular thalamus, is critical to regulating cue-induced reinstatement of cocaine-seeking. Int J Neuropsychopharmacol. 2011; 14:684-690. [PubMed: 21447232]

21. Shin HS, Cho HS, Sung KW, Yoon BJ. Orexin-A increases cell surface expression of AMPA receptors in the striatum. Biochem Biophys Res Commun. 2009; 378:409-413. [PubMed: 19028455]

22. Marcus JN, Aschkenasi CJ, Lee CE, Chemelli RM, Saper CB, Yanagisawa M, Elmquist JK. Differential expression of orexin receptors 1 and 2 in the rat brain. J Comp Neurol. 2001; 435:625. [PubMed: 11370008]

23. Trivedi P, Yu H, MacNeil DJ, Van der Ploeg LH, Guan XM. Distribution of orexin receptor mRNA in the rat brain. FEBS Lett. 1998; 438:71-75. [PubMed: 9821961]

24. Cluderay JE, Harrison DC, Hervieu GJ. Protein distribution of the orexin-2 receptor in the rat central nervous system. Regul Pept. 2002; 104:131-144. [PubMed: 11830288]

25. Hervieu GJ, Cluderay JE, Harrison DC, Roberts JC, Leslie RA. Gene expression and protein distribution of the orexin-1 receptor in the rat brain and spinal cord. Neuroscience. 2001; 103:777797. [PubMed: 11274794]

26. Pickens CL, Airavaara M, Theberge F, Fanous S, Hope BT, Shaham Y. Neurobiology of the incubation of drug craving. Trends Neurosci. 2011; 34:411-420. [PubMed: 21764143]

27. Conrad KL, Tseng KY, Uejima JL, Reimers JM, Heng LJ, Shaham Y, Marinelli M, Wolf ME. Formation of accumbens GluR2-lacking AMPA receptors mediates incubation of cocaine craving. Nature. 2008; 454:118-121. [PubMed: 18500330]

28. Mameli M, Halbout B, Creton C, Engblom D, Parkitna JR, Spanagel R, Lüscher C. Cocaineevoked synaptic plasticity: persistence in the VTA triggers adaptations in the NAc. Nat Neurosci. 2009; 12:1036-1041. [PubMed: 19597494]

29. Loweth JA, Tseng KY, Wolf ME. Adaptations in AMPA receptor transmission in the nucleus accumbens contributing to incubation of cocaine craving. Neuropharmacology. 2013 pii: S00283908(13)00233-5. 10.1016/j.neuropharm.2013.04.061 
30. Nair SG, Golden SA, Shaham Y. Differential effects of the hypocretin 1 receptor antagonist SB 334867 on high-fat food self-administration and reinstatement of food seeking in rats. Br J Pharmacol. 2008; 154:406-416. [PubMed: 18223663]

31. Plaza-Zabala A, Martín-García E, de Lecea L, Maldonado R, Berrendero F. Hypocretins regulate the anxiogenic-like effects of nicotine and induce reinstatement of nicotine-seeking behavior. $\mathrm{J}$ Neurosci. 2010; 30:2300-2310. [PubMed: 20147556]

32. Paxinos, G.; Watson, C. The Rat Brain in Stereotaxic Coordinates. Academic Press; San Diego, CA, USA: 1998.

33. Borgland SL, Storm E, Bonci A. Orexin B/hypocretin 2 increases glutamatergic transmission to ventral tegmental area neurons. Eur J Neurosci. 2008; 28:1545-1556. [PubMed: 18793323]

34. Ferrario CR, Loweth JA, Milovanovic M, Ford KA, Galiñanes GL, Heng LJ, Tseng KY, Wolf ME. Alterations in AMPA receptor subunits and TARPs in the rat nucleus accumbens related to the formation of $\mathrm{Ca}^{2+}$-permeable AMPA receptors during the incubation of cocaine craving. Neuropharmacology. 2011; 61:1141-1151. [PubMed: 21276808]

35. Li X, Wolf ME. Brain-derived neurotrophic factor rapidly increases AMPA receptor surface expression in rat nucleus accumbens. Eur J Neurosci. 2011; 34:190-198. [PubMed: 21692887]

36. Wolf ME. The Bermuda Triangle of cocaine-induced neuroadaptations. Trends Neurosci. 2010; 33:391-398. [PubMed: 20655604]

37. Lüscher C, Malenka RC. Drug-evoked synaptic plasticity in addiction: from molecular changes to circuit remodeling. Neuron. 2011; 69:650-663. [PubMed: 21338877]

38. Argilli E, Sibley DR, Malenka RC, England PM, Bonci A. Mechanism and time course of cocaineinduced long-term potentiation in the ventral tegmental area. J Neurosci. 2008; 28:9092-9100. [PubMed: 18784289]

39. Mahler SV, Smith RJ, Moorman DE, Sartor GC, Aston-Jones G. Multiple roles for orexin/ hypocretin in addiction. Prog Brain Res. 2012; 198:79-121. [PubMed: 22813971]

40. Zhang GC, Mao LM, Liu XY, Wang JQ. Long-lasting up-regulation of orexin receptor type 2 protein levels in the rat nucleus accumbens after chronic cocaine administration. J Neurochem. 2007; 103:400-407. [PubMed: 17623047]

41. Jacobs EH, Smit AB, de Vries TJ, Schoffelmeer AN. Neuroadaptive effects of active versus passive drug administration in addiction research. Trends Pharmacol Sci. 2003; 24:566-573. [PubMed: 14607079]

42. Mu P, Moyer JT, Ishikawa M, Zhang Y, Panksepp J, Sorg BA, Schlüter OM, Dong Y. Exposure to cocaine dynamically regulates the intrinsic membrane excitability of nucleus accumbens neurons. J Neurosci. 2010; 30:3689-3699. [PubMed: 20220002]

43. Ahmed SH, Koob GF. Transition from moderate to excessive drug intake: change in hedonic set point. Science. 1998; 282:298-300. [PubMed: 9765157]

44. Vanderschuren LJ, Everitt BJ. Drug seeking becomes compulsive after prolonged cocaine selfadministration. Science. 2004; 305:1017-1019. [PubMed: 15310907]

45. Gozzi A, Turrini G, Piccoli L, Massagrande M, Amantini D, Antolini M, Martinelli P, Cesari N, Montanari D, Tessari M, Corsi M, Bifone A. Functional magnetic resonance imaging reveals different neural substrates for the effects of orexin-1 and orexin-2 receptor antagonists. PLoS One. 2011; 6:e16406. [PubMed: 21307957] 
1. Intra-NAc hypocretin-1 does not modify AMPA or NMDA receptor surface expression

2. Surface Hcrtr-2 in NAc is unchanged during AMPAR plasticity in cocaine withdrawal

3. Hypocretins may not contribute to basal or cocaine-induced plasticity in the NAc 
A

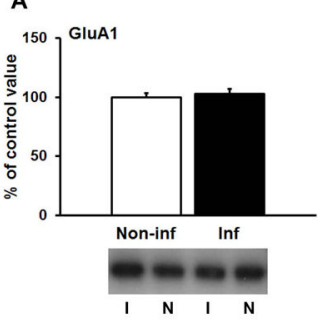

D

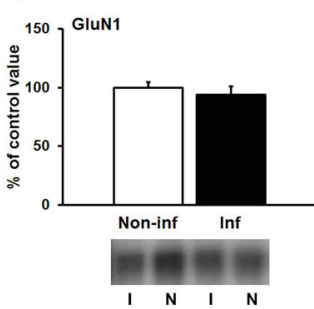

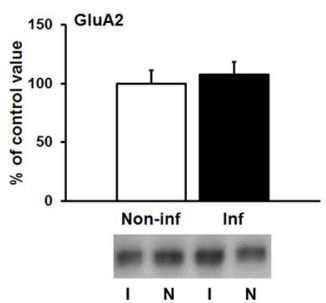

E

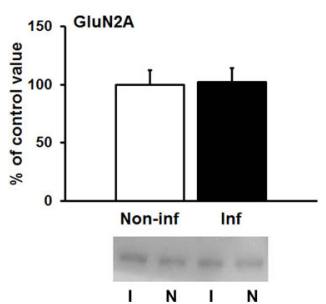

C

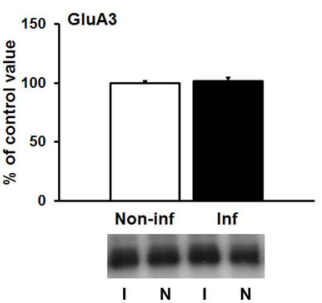

F

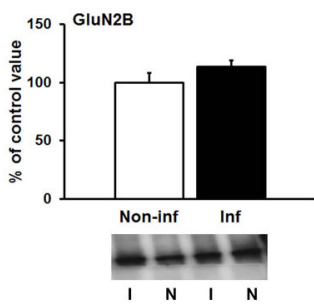

Figure 1.

Hypocretin-1 infusion into the NAc of drug-naïve rats does not modify glutamate receptor surface expression $30 \mathrm{~min}$ later. After unilateral infusion of hypocretin-1, NAc tissue was dissected from infused (I) and non-infused (N) hemispheres and biotinylated. Surfaceexpressed AMPAR (A-C) and NMDAR receptor subunits (D-F) were quantified by immunoblotting. 
A

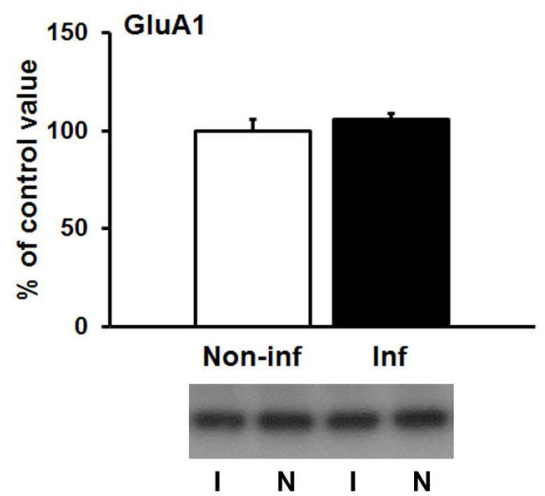

D

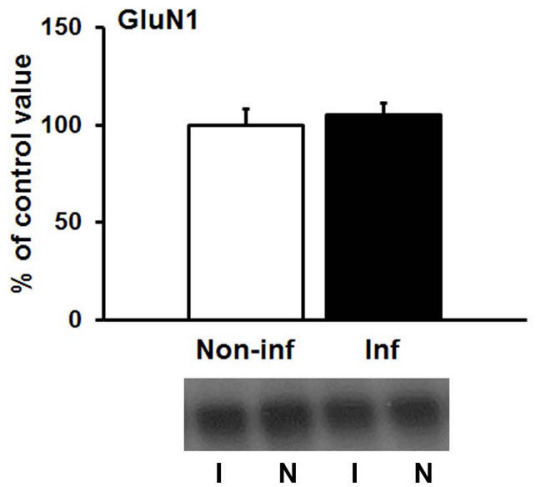

B

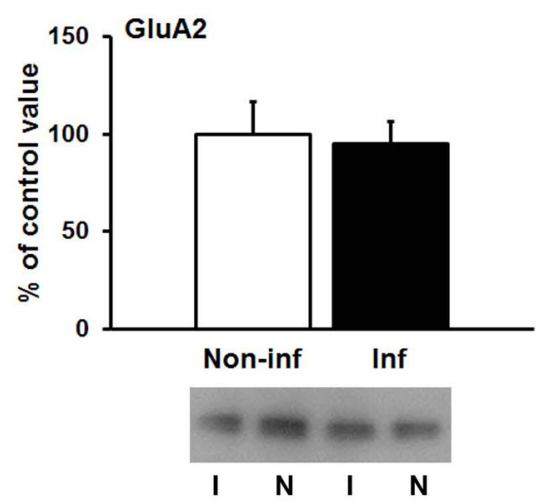

E

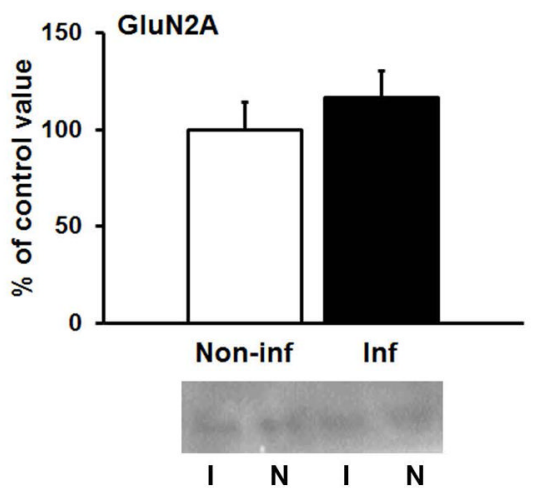

C

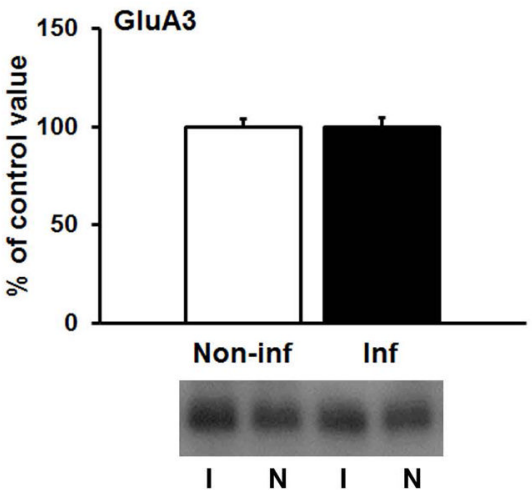

$\mathbf{F}$

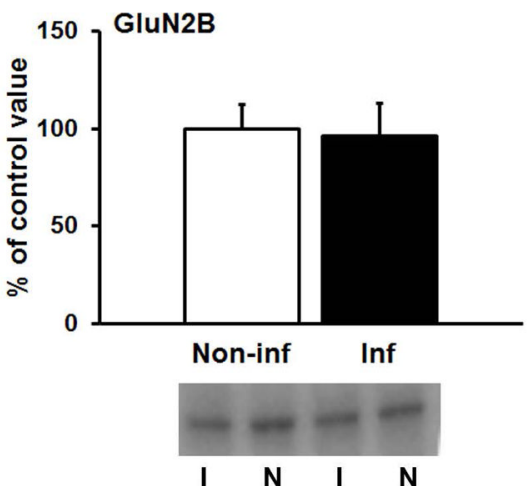

Figure 2.

Hypocretin-1 infusion into the NAc of drug-naïve rats does not modify glutamate receptor surface expression 3 hours later. After unilateral infusion of hypocretin-1, NAc tissue was dissected from infused (I) and non-infused (N) hemispheres and biotinylated. Surfaceexpressed AMPAR (A-C) and NMDAR receptor subunits (D-F) were quantified by immunoblotting. 
A

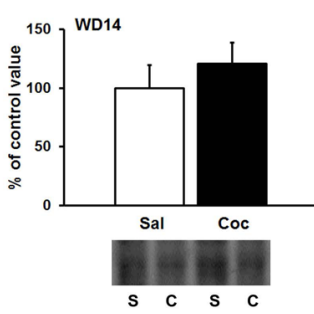

B

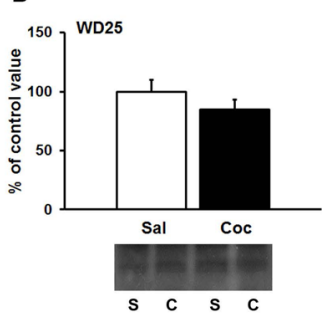

C

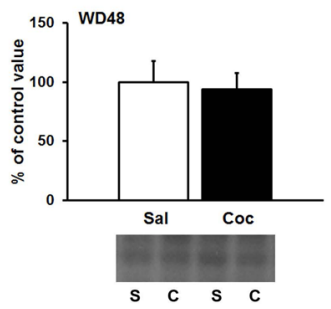

Figure 3.

Hypocretin receptor-2 (Hcrtr-2) surface expression in the NAc is not altered after (A) 14, (B) 25 or (C) 48 days of withdrawal from extended-access cocaine self-administration. Surface-expressed Hcrtr-2 was quantified by biotinylation in cocaine (C) and saline (S) exposed rats. WD, withdrawal day. 